
MANAGEMENT AND ACCOUNTING

Fakultas Ekonomi Universitas Andi Djemma

Jl. Puang H. Daud No 4 Kota Palopo, Email: jemma.unanda@gmail.com

\title{
PENGARUH KOMPETENSI DAN MOTIVASI TERHADAP KINERJA PEGAWAI PADA BALAI BESAR INDUSTRI HASIL PERKEBUNAN MAKASSAR
}

\section{Penulis \\ ${ }^{1}$ Erny Amriani Asmin \\ ${ }^{2}$ A. Rachman Supu}

STKIP Pembangunan Indonesia Makassar

\begin{tabular}{l}
\hline Info Artikel \\
\hline p-ISSN : 2615-1871 \\
e-ISSN : 2615-5850 \\
Volume 2 Nomor 1, Maret 2019
\end{tabular}

Email: erny.amriani123@gmail.com

Received 8th January 2019 / Accepted 28th February 2019

\begin{abstract}
ABSTRAK
Penelitian ini bertujuan untuk mengetahui dan menganalisis pengaruh kompetensi dan motivasi terhadap kinerja pegawai Balai Besar Industri Hasil Perkebunan Makassar dan variable yang memberikan pengaruh dominan. Metode yang digunakan yaitu analisis deskriptif untuk mendeskriptifkan atau memberikan gambaran tentang objek yang diteliti dan Analisa Regresi Berganda (Multiple Regression). Hasil penelitian menunjukkan bahwa secara simultan faktor kompetensi antara lain : pengetahuan, keterampilan, pengalaman kerja dan motivasi perpengaruh positif dan signifikan terhadap kinerja pegawai. Sementara Tingkat pengetahuan terbukti berpengaruh dominan dan signifikan terhadap kinerja pegawai pada Balai Besar Industri hasil Perkebunan Makassar.
\end{abstract}

Kata Kunci: Kompetensi, Motivasi dan Kinerja

\section{PENDAHULUAN}

Kualifikasi sumber daya manusia adalah merupakan kemampuan organisasi melakukan penilaian terhadap kompetensi para pegawai disemua lini. Pengembangan kompetensi dan ketepatan dalam memposisikan pegawai pada suatu jenjang struktur melalui suatu sistem analisis pekerjaan (job analysis) dan analisis kompetensi sumber daya manusia yang akurat. Hal ini dapat terwujud dengan pendekatan konsep manajemen sumber daya manusia yang sesuai dengan kebutuhan atau tuntutan organisasi terutama tuntutan kondisi eksternal yang semakin cepat, perubahan dan diwarnai oleh ketidak pastian.

Balai Besar Industri Hasil Perkebunan Makassar merupkan suatu instansi yang membutuhkan sumber daya manusia (SDM) yang profesional dan handal, baik kaitannya dengan akademik maupun administrasi. Peningkatan kinerja secara efektif bagi Pegawai Negeri Sipil (PNS) di Lingkungan Balai Besar Industri Hasil Perkebunan Kementerian Perindustrian tentunya tidak mudah diaplikasikan secara utuh. Untuk itu, dalam menunjang dan mempercepat proses kerja serta berbagai aktivitas kerja lainnya tidak terlepas dari upaya meningkatkan kualitas atau profesionalisme para pegawai dalam 
melaksanakan tugas yang diwenangkan kepada mereka untuk menunjang kelancaran kerja dan pencapaian hasil kerja yang memuaskan.

Keberadan pegawai Negeri Sipil atau (PNS) sangat dibutuhkan dalam rangka pemberian pelayanan umum kepada masyarakat.Pegawai perlu diberikan dan dilakukan pembinaan yang sistimatis melalui berbagai kebijaksanaan dan instrument pembinaan. Salah satu instrument itu dapat mengalahkan pegawai pada tingkat kompetensi yang diinginkan. Sistim penilaian kinerja atau prestasi kerja pada pegawai negeri sipil secara formal tertuang pada PP.10 tahun 1979 tentang penilaian pelaksanaan pekerjaan (PNS) atau lebih dikenal dengan DP3 (daftar penilaian pelaksanaan pekerjaan) pegawai negeri sipil.

Penilian kinerja di lingkungan pegawai negeri sipil (PNS) dikenal dengan sebutan penilaian pelaksanaan pekerjaan. Penilaian pelaksanaan kinerja tersebut dilaksanakan menggunakan daftar penilaian pelaksanaan pekerjaan (DP3), dengan unsur-unsur yang terdapat di dalamnnya, meliputi, kesetiaan, prestasi kerja, tanggung jawab, ketaatan, kejujuran, kerjasama, prakarsa dan kepemimpinan.

Menurut pengamatan awal peneliti, bahwa selama ini kinerja para pegawai pada Balai Besar Industri Hasil Perkebunan belum mampu memberikan kontribusi opimal terhadap proses kerja dan hasil yang memuaskan. Adanya pengetahuan (kemampuan), keterampilan, pengalaman kerja dan pemberian motivasi juga berarti memberikan kesempatan kepada pegawai untuk mampu mengembangkan kemampuan dan merupakan dorongan semaksimal mungkin pegawai untuk berproduksi.Pemberian motivasi berupa penghargaan dan kesejahteraan pegawai mampu mengembangkan kemampuan dan merupakan dorongan semaksimal mungkin pegawai untuk berprestasi.

Pembentukan kompetensi dan profesionalisme pegawai terhadap pelaksanaan pekerjaan perlu diarahkan menuju program yang sesuai standar kompetensi yang telah ditetapkan .Peran kompetensi sangat diperlukan dalam prestasi kerja pegawai. Pegawai yang mempunyai kompetensi kerja yang baik tentu akan mudah untuk melaksanakan semua tanggung jawab pekerjaan. Mampu membaca situasi dan permasaalahan yang terjadi dalam pekerjaan serta dapat memberikan respon yang tepat dan memiliki penyesuaian diri yang baik dengan lingkungannya. Sebagai contoh seorang yang pada awalnya mempunyai prestasi kerja yang berupa karier memduduki posisi jabatan tertentu misalnya kepala Sub Bagian (Kasie), kemudian melewati banyak situasi dan peluang yang terhampar selama menyusuri perjalanan kariernya dapat bebelok dan diantaranya yang melompat menduduki jabatan Kepala Bidang (Kabid), tetapi banyak pula yang tepat dijalur profesi Kepala Sub Bagian atau Kasie), karena mengalami stagnasi dalam perkembangan kariernya, tentu saja hal ini perlu diketahui mengapa pegawai tersebut tidak dapat meningkatkan prestasinya.

\section{Rumusan Masalah}

Berdasarkan latar belakang di atas, maka dikemukanan masalah sebagai berikut:

1. Apakah kompetensi yang terdiri dari variable pengetahuan, keterampilan, pengalaman kerja dan motivasi secara simultan berpengaruh terhadap kinerja pegawai Balai Besar Industri Hasil Perkebunan Makassar

2. Variabel manakah yang paling dominan mempengaruhi kinerja pegawai pada Balai Besar Industri Hasil Perkebunan Makassar.

\section{Tujuan Penelitian}

Adapun yang menjadi tujuan penelitian adalah:

1. Untuk mengetahui dan menganalisis pengaruh kompetensi dan motivasi terhadap kinerja pegawai Balai Besar Industri Hasil Perkebunan Makassar 
2. Untuk mengetahui dan menganalisis variable yang memberikan pengaruh dominan terhadap kinerja pegawai pada Balai Besar Industri Hadil Perkebunan Makassar

\section{TINJAUAN PUSTAKA}

\section{Manajemen Sumber Daya Manusia}

Menurut Veithzal (2009:2-3) manajemen sumber daya manusia merupakan system yang terdiri dari banyak aktivitas interdependen (saling terkait satu sama lain). Manajemen SDM juga merupakan sistem terbuka yang dipengaruhi oleh lingkungan luar. Lebih lanjut Veithzal (2009:6) juga mengungkapkan bahwa sumber daya manusia perlu dikelola secara baik dan professional agar tercipta keseimbangan antara kebutuhan SDM dengan tuntutan serta kemajuan suatu organisasi/ perusahaan. Bila pengelolaan SDM dapat dilaksanakan secara professional, diharapkan SDM dapat bekerja secara produktif.

Sudah merupakan tugas manajemen sumber daya manusia untuk mengelola manusia seefektif mungkin agar diperoleh suatu satuan sumber daya manusia yang merasa puas dan memuaskan. Manajemen sumber daya manusia merupakan bagian dari manajemen umum yang memfokuskan diri pada sumber daya manusia. Penjelasan tentang sumber daya manusia diungkapkan pula oleh Amiruddin (2001: 47) bahwa sumber daya manusia adalah unsur komponen penting dalam berbagai aktivitas kehidupan diperuntukkan untuk menghasilkan nilai ekonomis.

\section{Kompetensi}

Clellend dalam sedarmayanti (2007:126-127) memberi penjelasan masing- masing komptensi adalah sebagai berikut:

1. Keterampilan: keahlian/kecakapan melakukan sesuatu dengan baik.contoh kemampuan dalam mengoperasikan computer

2. Pengetahuan: Informasi yang dimiliki/dikuasai seseorang dalam bidang tertentu, contoh mengasai ilmu manajemen.

3. Peran sosial: Citra yang diproyeksikan seseorang kepada orang lain, contoh: menjadi seorang pengikut.

4. Citra diri: depresi individu tentang dirinya, contoh melihat/mempromosikan dirinya sebagai pemimpin.

5. Sifat/ciri, karakteristik yang relative konstan pada tingkah laku seseorang, contoh seseorang pendengar yang baik.

6. Motif, pemikiran/niat dasar konstanta yang mendorong mempengaruhi orang lain

Keterampilan dan pengetahuan lebih muda dikenali juga relative lebih mudah dibentuk dan dikembangkan melalui proses belajar dan pelatihan yang relative singkat. Peran sosial, citra diri dan motif tidak muda diidentifikasi dan lebih sulit serta membutuhkan waktu lebih lama untuk memperbaiki/mengembangkannya. Keterampilan dan pengetahuan memiliki peranan penting dalam keberhasilan seseorang, sedangkan empat kompetensi lainnya memainkan peran yang jauh lebih besar. Hal ini lebih terasa pada pekerjaan yang lebih strategis dalam sebuah organisasi. Kompetensi merupkan faktor atau kunci penentu bagi seseorang dalam menghasilkan kinerja yang sangat baik dan juga merupakan penentu dalam keberhasilan suatu organisasi.

\section{Pengetahuan}

Justhill (2000:66) mengemukakan bahwa pengertian pengetahuan adalah suatu rangkaian proses pemanfatan suatu pemahaman yang dikemas dalam berbagai penerimaan informasi yang terpampang dalam suatu wawasan yang dilakukan sesuai ting- 
kat komunikasi secara sadar dalam menghasilkan suatu pengertian yang bermakna dan bermanfaat. Pengertian ini merupakan rujukan dalam menentukan indikator tingkat pengetahuan yang terdiri dari empat faktor yaitu:

a. Penerimaan informasi, yaitu yang diterima oleh syaraf otak menjadi sebuah pengetahuan yang dikenal.

b. Wawasan, yaitu pemanfaatan oleh informasi yang tersimpan dalam memori saraf otak manusia.

c. Pengkomunikasian, yaitu membahas dan membicarakan berbagai penerima informasi dalam wawasan yang terdapat dalam saraf otak manusia.

d. Kesadaran, yaitu menyadari informasi yang diterima sesuai tingkat pemanfaatan wawasan yang dikominikasikan dengan baik dan menghasilkan buah pikiran yang disebut pengetahuan.

\section{Keterampilan}

Bebarapa teori yang membahas manajemen sumber daya manusia yang menyangkut dengan keterampilan dan berkaitan dengan kualitas sumber daya manusia, antara lain:

a. Teori kemandirian (independent theory) dikemukakan oleh Wankel (2000:149) yang menyatakan kemandirian sumber daya manusia berasal dari keterampilan yang dimiliki yang dapat menciptakan berbagai peluang dan kreasi untuk menghasilkan penilaian tentang kualitas kerja.

b. Teori kehandalan (tangible theory) dikemukakan oleh Nelson (1999:82) bahwa kehandalan adalah menguasai sesuatu berdasarkan keterampilan dan bakat yang tinggi untuk meraih cita-cita yang mulia dalam pentas kualitas dan kebutuhan peradaban manusia.

\section{Pengalaman Kerja}

Teori pengalaman kerja dalam kaitannya dengan kualitas sumber daya manusia dapat dilihat dari teori yang dikemukakan oleh Starman dan McGregor dalam Robinson (1999:236) sebagai berikut:

a. Teori Starman yang melihat bahwa kekuatan, keunggulan, kehandalan seseorang tercermin dari pengalaman yang mewarnai kehidupannya. Teori ini dikemukakan oleh Starman pada saat meghadapi suatu pemasaalahan yang sangat kompleks, namun permasaalahan tersebut telah dicoba dipahami berdasarkan kemampuan mengingat aktivitas yang pernah dilakkan dan dari akumulasi aktivitas tersebut ditentukan adanya suatu pengalaman yang berharga yang dapat memecahkan permasaalahan tersebut yang disebut pengalaman keja. Makin sering melakukan sesuatu, maka frekuensi pengalaman makin tinggi yang menyebabkan kualitas yang dimiliki makin kuat.

b. Teori McGregor menyatakan pengalaman adalah guru yang paling berharga. Interprestasi McGregor tersebut didasari bahwa banyaknya permasaalahan yang dapat dipecahkan, tidak terlepas dari peranan pengalaman yang menuntun untuk mampu me ngatasi permasaalahan tersebut.

\section{Motivasi}

Teori motivasi yang dikemukakan oleh Abraham Maslow dalam Sudarmayanti (2007:234) mengungkapkan bahwa dalam setiap manusia terdapat 5 (lima) tingkat kebutuhan yaitu:

1. Fisiologis, antara lain: rasa lapar, haus, perlindungan (pakaian dan perumahan), seks dan kebutuhan lain. 
2. Keamanan, antara lain: keselamatan dan perlindungan terhadap kerugian fisik dan emosional.

3. Sosial, mencakup: kasih sayang, rasa dimiliki, diterima baik dan persahabatan.

4. Penghargaan mencakup: faktor rasa hormat internal, seperti harga diri, otonomi dan prestasi, faktor eksternal seperti status, pengakuan dan perhatian

5. Aktualisasi diri, yaitu dorongan untuk menjadi apa yang ia menjadi mencakup pertumbuhan, mencapai potensialnya, dan pemenuhan diri.

\section{Kinerja Pegawai}

The Scribner Bantam English Dictionery dalam Prawirosentono 2000:1) performance berasal dari kata to perform mempunyai beberapa entries. Arti dari entries tersebut adalah sebagai berikut:

1. Melakukan, menjalankan, dan melaksanakan

2. Memenuhi atau menjalankan kewajiban suatu nazar

3. Menggambarkan suatu karakter dalam suatu pekerjaan

4. Menggambarkan dengan suara atau alat music

5. Melaksanakan atau menyempurnakan tanggung jawab

6. Melakukan suatu kegiatan dalam suatu permainan

7. Memainkan (pertunjukan) music

8. Melakukan sesuatu yang diharapkan oleh seserang atau mesin.

Sedangkan dalam pedoman Penyusunan Pelaporan Akuntabilitas (LAN) memberikan pengertian kinerja sebagai ukuran kuantitatif dan kualitatif yang mengambarkan tingkat pencapaian suatu sasaran atau tujuan yang telah ditetapkan dengan memperhitungkan indikator masukan, keluaran, hasil, manfaat, dan dampak (LAN RI, 1999).

\section{Hipotesis}

1. Bahwa variable kompetensi yang terdiri dari: pengetahuan, keterampilan, pengalaman kerja dan motivasi berpengaruh terhadap kinerja pegawai pada Balai Besar Industri Hasil Perkebunan Makassar (BBIHP).

2. Variabel pengetahuan berpengaruh paling dominan terhadap kinerja pegawai pada Balai Besar Industri Hasil Perkebunan Makassar

\section{METODE PENELITIAN}

\section{Objek dan Waktu Penelitian}

Penelitian ini akan dilaksanakan pada Balai besar Industri hasil Perkebunan Makassar, dan objek penelitian adalah Balai Besar Industri hasil Perkebunan Makassar (BBIHP) Makassar. Waktu penelitian selama 3 (tiga) bulan yaitu dari bulan Desember 2012 sampai dengan bulan Pebruari 2013.

\section{Metode Pengumpulan Data}

Metode pengumpulan data yang digunakan dalam penelitian ini dimaksudkan untuk memperoleh data yang relevan dan akurat dengan permasaalahan yang diteliti. Metode pengumpulan data tersebut sebagai berikut:

1. Observasi adalah pengamatan secara langsung terhadap faktor-faktor sumber daya manusia yang cenderung memiliki hubungan dengan variabel penelitian.

2. Wawancara adalah dialog secara langsung dengan para responden yaitu pegawai untuk memperoleh data yang relevan. 
3. Kuisioner adalah teknik pengumpulan data dengan mengajukan sejumlah pertanyaan secara tertulis dan diberikan kepada setiap responden untuk mendapatkan jawaban yang akurat dan valid.

4. Dokumentasi adalah data yang diperoleh melalui pencatatan dokumen yang terdapat pada lokasi penelitian yang berhubungan dengan variabel penelitian ini.

\section{Jenis dan Sumber data}

1. Data primer, adalah data yang diperoleh melalui penelitian langsung terhadap objek yang diteliti, bersumber dri observasi dan hasil kuisioner yang diberikan kepada responden

2. Data sekunder adalah data yang diperoleh dari dokumen-dokumen tertulis pada objek penelitian serta sumber lain yang terkait dengan penelitian ini.

\section{Populasi dan Sampel}

Populasi dalam penelitian ini adalah pegawai negeri sipil pada Balai Besar Industri hasil Perkebunan Makassar yang berjumlah 91 orang untuk keakuratan penelitian ini maka peneliti akan mengambil seluruh subjek sebagai responden penelitia dengan menggunakan metode yang digunakan adalah metode sensus.

\section{Metode Analisis Data}

Untuk menganalisis data dalam penelitian ini, maka digunakan yaitu meliputi 1. Analisis Deskriptif

Analisis deskriptif dimaksudkan untuk mendeskriptifkan atau memberikan gambaran tentang objek yang diteliti

2. Analisa Regresi Berganda (Multiple Regression )

Metode ini digunakan untuk melihat seberapa besar pengaruh kompetensi dan motivasi terhadap kinerja pegawai pada Balai Besar Industri Hasil Perkebunan Makassar dengan menggunakan rumus

Dimana;

$$
\mathrm{Y}=\mathrm{bo}+\mathrm{b} 1 \mathrm{X} 1+\mathrm{b} 2 \mathrm{X} 2+\mathrm{b3X3}+\mathrm{b} 4 \mathrm{X} 4+\mathrm{e} 1
$$

$\mathrm{Y}=$ Kinerja Pegawai; X1 = Pengetahuan; X2 = Keterampilan $/$ skill; X3 = Pengalaman kerja/ Experience; X4 = Motivasi; bo $=$ Konstanta; b1, b2, b3, b4 = Koefisien regresi; dan e $1=$ Faktor kesalahan.

Selanjutnya untuk menentukan pengaruh dan tingkat signifikan baik secara personil maupun secara bersama-sama maka dilakukan uji-t dan uji-F menggunakan program SPSS.

\section{HASIL DAN PEMBAHASAN}

\section{Analisis Deskriptif}

Berikut akan dijelaskan Karakteristik Responden yaitu

1. Menurut Tingkat Pendidikan

Tabel 1. Distribusi Responden Menurut Tingkat Pendidikan.

\begin{tabular}{|l|c|c|}
\hline \multirow{2}{*}{ Pendidikan } & \multicolumn{2}{|l|}{ Responden } \\
\cline { 2 - 3 } & Frekuwensi (orang) & Persentase (\%) \\
\hline Strata Dua (S2) & 17 & 18 \\
\hline Strata Satu(S1) & 53 & 58,24 \\
\hline Diploma & 7 & 7,96 \\
\hline SLTA & 14 & 15,38 \\
\hline Jumlah & 91 & 100 \\
\hline
\end{tabular}

Sumber. Kepegawaian Balai Besar Industri Hasil Perkebunan 
Tabel 1 menunjukkan bahwa pegawai pada Balai Besar Industri Hasil Perkebunan Makassar memiliki tingkat pendidikan Stara dua (S2) yaitu sebanyak 17 orang atau 18 $\%$, Strata Satu (S1) sebanyak 53 orang atau 58,24\%, Diploma memiliki sebanyak 7 orang atau 7,96 \%, dan SLTA sebanyak 14 orang atau 15,38 \%. Pegawai pada Balai Besar Industri Hasil Perkebunan Makassar didominasi yang berpendidikan Stara satu (S1).

2. Menurut Golongan

Tabel. 2 Distribusi Responden Menurut Golongan

\begin{tabular}{|c|c|c|}
\hline \multirow{2}{*}{ Golongan } & \multicolumn{2}{|l|}{ Responden } \\
\cline { 2 - 3 } & Frekuensi(orang) & Presentase \\
\hline IV & 16 & 17,58 \\
\hline III & 72 & 79 \\
\hline II & 3 & 3,29 \\
\hline Jumlah & 91 & 100 \\
\hline
\end{tabular}

Sumber: Kepagawaian Balai Besar Industri Hasil Perkebunan Makassar

Berdasarkan Tabel 2, dapat dilihat bahwa dominan pegawai pada Balai Besar Industri Hasil Perkebunn Makassar golongan III, yaitu sebanyak 72 orang atau 79\%, Golongan IV sebanyak 16 orang atau 17,58\%, dan golongan II sebanyak 3 orang atau $3,29 \%$

3. Menurut Jabatan

Tabel 3. Distribusi Responden Menurut Jabatan

\begin{tabular}{|l|c|c|}
\hline \multirow{2}{*}{\multicolumn{1}{|c|}{ Jabatan }} & \multicolumn{2}{c|}{ Responden } \\
\cline { 2 - 3 } & Frekuensi (orang) & Presentase (\%) \\
\hline Kepala Balai & 1 & 1 \\
\hline Kepala Bidang /Ka.Bag & 4 & 4 \\
\hline Ka.sie & 9 & 10 \\
\hline Staf/Fungsional & 78 & 86 \\
\hline Jumlah & 91 & 100 \\
\hline
\end{tabular}

Sumber: Kepegawaian Balai Besar Industri Hasil Perkebunan Makassar

Tabel 3 menunjukkan bahwa pegawai yang menjabat sebagai Staf/fungsional memiliki persentase terbanyak yaitu $86 \%$ ini berarti seluruh pegawai Balai Besar Industri Hasil Perkebunan hanya dikepalai oleh (1) satu orang Kepala Balai dibantu oleh 3 kepala Bidang 1 Kabag Tata Usaha dan 9 orang kepala seksi, sedangkan 78 orang adalah staf/fungsional.

\section{Analisis Regresi Berganda}

Berdasarkan deskripsi variable penelitian maka dapat diketahui besarnya pengaruh kompetensi terhadap prestasi kerja pegawai pada Balai Besar Industri hasil Perkebunan dengan menggunakan analisa regresi linier berganda Program computer SPSS 13.00 sebagai berikut:

\section{Uji-F}

Uji-F dilkaukan berdasarkan table Anova, gunanya untuk mengetahui besarnya angka probabilitas atau signifikansi (sig) dari variable bebas $(\mathrm{X})$ terhadap variable terikat (Y) yang diteliti. Berdasarkan tabel Anova, dapat diketahui apakah variable kompetensi yang terdiri dari variabel pengetahuan, keterampilan, pengalaman kerja dan motivasi berpengaruh secara bersama-sama terhadap kinerja pegawai pada Balai Besar Industri Hasil Perkebunan Makassar. 
Tabel 4. Uji Anova

ANOVA $^{\mathrm{b}}$

\begin{tabular}{|c|c|c|c|c|c|}
\hline Model & $\begin{array}{l}\text { Sum of } \\
\text { Squares }\end{array}$ & Df & Mean Square & $\mathrm{F}$ & Sig \\
\hline $\begin{array}{l}\text { Regression } \\
\text { Residual } \\
\qquad \text { Total }\end{array}$ & $\begin{array}{l}10,358 \\
6,488 \\
16,846\end{array}$ & $\begin{array}{l}4 \\
70 \\
74\end{array}$ & $\begin{array}{l}2,589 \\
, 093\end{array}$ & 27,939 & $.000^{\mathrm{a}}$ \\
\hline
\end{tabular}

Predictor : (constanta), Motivasi, Pengalaman,Pengetahuan, Keterampilan

Dependen Variabel : Kinerja

Tabel 4 di atas menunjukkan bahwa uji Anova menhasilkan angka $\mathrm{F}$ sebesar 27,939 dengan tingkat signifikansi (angka probabilitas sebesar 0,000). Karena angka probabilitas $0,000<0,05$, maka dengan kata lain variable bebas $(\mathrm{X})$ yang terdiri dari pengetahuan (X1), keterampilan (X2), pengalaman kerja (X3), dan motivasi (X4) secara bersama-sama berpengaruh terhadap variable terikat $(\mathrm{Y})$ yaitu kinerja.

2. Uji-t

Uji-t dilakukan berdasarkan tabel coefficient dengan membandingkan probabilitas setiap variabel bebas $\mathrm{X}$ (pengetahuan, ketermpilan, pengalaman kerja,dan motivasi) dengan 0,05 (kesalahan), untuk mengetahui lebih lanjut hasil uji t-hitung sebagaimana dimaksud dapat dilihat pada Tabel 5 di bawah ini:

Tabel 5. Ringkasan Hasil Uji Secara Parsial dengan Perhitungan

Regresi Berganda

\begin{tabular}{|c|c|c|c|c|c|c|}
\hline \multirow{2}{*}{$\begin{array}{l}\text { Model } \\
\text { Hipotesis }\end{array}$} & \multicolumn{2}{|c|}{$\begin{array}{l}\text { Undestandardized } \\
\text { Coeffcients }\end{array}$} & \multirow[b]{2}{*}{ Beta } & \multirow[t]{2}{*}{$\mathrm{t}$} & \multirow[t]{2}{*}{ Sig. } & \multirow[t]{2}{*}{ Ket } \\
\hline & Beta & $\begin{array}{l}\text { Std } \\
\text { Error }\end{array}$ & & & & \\
\hline 1.Constant & $-0,923$ & 0,400 & - & $-2,306$ & 0,024 & \\
\hline Pengetahuan & 0,425 & 0,105 & 0,339 & 4.033 & 0,000 & Diterima \\
\hline Keteramplan & 0,334 & 0,110 & 0,288 & 3,026 & 0,003 & Diterima \\
\hline Pengalaman & 0,189 & 0,187 & 0,187 & 2.451 & 0,017 & Diterima \\
\hline Motivasi & 0,295 & 0,268 & 0,268 & 2,730 & 0,008 & Diterima \\
\hline
\end{tabular}

Sumber: Data diolah, 2013

Pada Tabel 5 menujukkan bahwa hasil yang diperoleh sebagai berikut:

1. Probalitas variabel X1 (pengetahuan) adalah $0,000<0,05$ berarti pengetahuan memberi pengaruh yang positif dan signifikan terhadap kinerja pegawai (Y)

2. Probabilitas $\mathrm{X} 2$ (keterampilan) adalah $0,003<0,05$ berarti keterampilan memberi pengaruh yang positif dan signifikan terhadap kinerja pegawai $(\mathrm{Y})$

3. Probalitas X3 (pengalaman kerja) adalah $0,017<0,05$ berarti pengalaman kerja memberi pengaruh yang positif dan signifikan terhadap kinerja pegawai (Y)

4. Probalitas X4 (motivasi) adalah $0,008<0,05$ berarti bahwa motivasi memberi pengaruh positif dan signifikan terhadap kinerja pegawai (Y)

Untuk mengetahui hasil uji t-hitung dapat dilihat pada Tabel 6 di bawah ini: 
Tabel 6 Uji t-hitung Coefficients

\begin{tabular}{|c|c|c|c|c|c|c|c|}
\hline \multirow{2}{*}{ Model } & \multicolumn{2}{|c|}{$\begin{array}{c}\text { Unstandardized } \\
\text { coefficients } \\
\text { Standardized } \\
\text { Coefficients }\end{array}$} & $\begin{array}{c}\text { Standardized } \\
\text { Coefficients }\end{array}$ & & \multirow{2}{*}{ Sig } & \multicolumn{3}{|c|}{$\begin{array}{c}\text { Collinearty Sta- } \\
\text { tistics }\end{array}$} \\
\cline { 7 - 9 } & B & Std.Error & Beta & & & Tolerance & VIF \\
\hline Constanta &, 923 &, 400 & - & 2,306 &, 024 & - & - \\
\hline Pengetahuan &, 425 &, 105 &, 339 & 4,033 &, 000 &, 778 & 1,286 \\
\hline Keterampilan &, 334 &, 110 &, 288 & 3,026 &, 003 &, 609 & 1,641 \\
\hline Pengalaman &, 189 &, 077 &, 187 & 2,451 &, 017 &, 946 & 1,057 \\
\hline Motivasi &, 295 &, 108 &, 268 & 2,730 &, 008 &, 572 & 1,747 \\
\hline
\end{tabular}

a. Dependen Variabel : Kinerja Pegawai

Variabel bebas X yang paling dominan berpengaruh terhadap Y (kinerja pegawai) adalah X1 (Pengetahuan). Besarnya kontribusi masing-masing variabel bebas (X1, X2, $\mathrm{X} 3$, dan $\mathrm{X} 4$ ) ditunjukkan pada persamaan regresi berikut ini:

$$
Y=-0,923+0,425 X 1+0,334 X 2+0,189 X 3+0,295 X 4
$$

Besarnya kontribusi pengetahuan (X1) terhadap kinerja pegawai (Y) adalah 0,425 jika para pegawai mampu meningkatkan pengetahuan dalam bekerja. Besarnya kontribusi keterampilan (X2) terhadap kinerja pegawai (Y) adalah 0,334 jika para pegawai mampu meningkatkan keterampilan dalam bekerja. Besarnya kontribusi pengalaman kerja (X3) terhadap kinerja pegawaia (Y) adalah 0,189 jika para pegawai memiliki pengalaman kerja lebih banyak. Besarnya kontribusi motivasi (X4) terhadap kinerja pegawai (Y) adalah 0,295 jika motivasi kerja ditingkatkan. Nilai konstanta sebesar -0,923 memiliki arti jika tidak ada variabel-variabel bebas yaitu pengetahuan (X1), keterampilan (X2), pengalaman kerja (X3) dan motivasi (X4) yang mempengaruhi maka kinerja pegawai pada Balai Besar Industri hasil Perkebunan menuruni sebesar -0,923 (konstanta).

\section{Pembahasan}

Pembahasan hasil penelitian mengenai pengaruh kompetensi terhadap kinerja pegawai pada Balai Besar Industri Hasil Perkebunan Makassar. Kompetensi pegawai yang dimaksud adalah pengetahuan, keterampilan, pengalaman dan motivasi yang merupakan variabel bebas dalam penelitian ini, sedangkan variabel terikatnya adalah kinerja pegawai. Lebih jelasnya dapat dilihat pada uraian pembahasan berikut:

\section{Pengaruh Pengetahuan Terhadap Kinerja Pegawai}

Kenyataan yang dapat dilihat dalam dinamika kerja Balai Besar Industri Hasil Perkebunan Makassar yaitu bahwa pengetahuan memainkan peranan penting dalam meningkatkan kinerja pegawai. Tingkat pengetahuan yang dimiliki pegawai mencerminkan adanya perbedaan kompetensi yang dimiliki pegawai dalam menjalankan tugas pokok dan fungsinya sesuai dengan aktivitas kerja yang dihadapi.Perbedaan tersebut tercermin dari tingkat pendidikan pegawai. Secara nyata pengaruh pengetahuan terhadap peningkatan kinerja dapat dilihat dari adanya perbedaan tingkat pendidikan yang dimiliki oleh setiap pegawai. Pegawai yang memiliki tingkat pendidikan yang tinggi diharapkan lebih banyak memainkan peranan di dalam mengembangkan organisasi ker- 
janya sesuai dengan tugas pokok dan fungsinya di dalam mengorganisir institusi atau organisasi.

Ini sesuai dengan pendapat Murtopo (2004: 187) bahwa dalam meningkatkan kompetensi individu sumber daya manusia, pengetahuan sangat berperan penting dalam mempengaruhi tingkat kemampuan penerimaan inovasi, adopsi, dan inisiatif dalam menjalankan tugas pokok dan fungsinya dalam suatu organisasi kerja. Pengathuan menjadi syarat mutlak untuk diperhatikan karena menjadi tolok ukur dalam meningkatka kompetensi sumber daya manusia. Pendapat di atas sangat sesuai dengan hasil penelitian ini yaitu bahwa pengetahuan sangat berpengaruh dominan terhadap pengingkatan prestasi kerja pegawai pada Balai Besar Industri Hasil Perkebunan Makassar.

\section{Pengaruh Keterampilan Terhadap Kinerja Pegawai}

Bentuk konkrit pengaruh keterampilan terhadap kinerja pegwai, tercermin dari kemampuan dalam menjalankaan dan melaksanakan akivitasnya sehari-hari. Keterampilan yang dimiliki oleh pegawai dalam mengimplementasikan aktivitasnya menghadapi dinmika kerja yang menuntut pemberian pelayanan yang optimal, maka diperlukan pegawai yang memiliki keterampilan yang cakap, handl yang ahli bidang-bidang uraian tugas yng diamanhkan sesuai dengan kemampuan keterampilan-keterampilan manajerial, teknis dan operasional dalam melaksnakan segala aktivitas kerja sehari-hari pada Balai Besar Industri hasil Perkebunan Makassar.

Berdasarkan kenyataan dan bentuk-bentuk konkrit yang ditentukan pada pegawai pada Balai Besar Industri Hasil Perkebunan Makassar, maka terbukti dari tanggapan responden bahwa keterampilan yang dimiliki oleh pegawai berpengaruh terhadap peningkatan prestsi kerja pegawai. Keterampilan yang ditunjukkan oleh setiap pegawai banyak ditentukan oleh tingkat kemampuan kehandalan dan keahlian pegawai dalam setiap aktivitas kerja yang dilakukan baik secara manajeril teknis dan operasional.

Konsep dan yang mendukung Sulastyo (2000: 154) menyatkan bahwa keterampilan sangat berperan penting dalam meningkatkan kualitas sumber daya manusia. Keterampilan ditentukan oleh kehandalan menyelesaikan tugas pokok tepat waktu, cakap dalam keterampilan proses kerja, dan memiliki dalam aplikasi tugas pokok. Hasil penelitian ini menunjukkan bahwa pengaruh keterampilan sebagai salah satu unsur kompetensi terhadap kinerja pegawai pada Balai Besar Industi Hasil Perkebunan Makassar juga memegang peranan penting, ini dibuktikan dalam tabel coefficients ${ }^{\mathrm{a}}$.nilai standardized coefficients Beta dari variabel keterampilan adalah 0,334.

\section{Pengaruh Pengalaman Kerja Terhadap Kinerja Pegawai}

Pengalaman kerja merupakan salah satu factor yang mempengaruhi kinerja pegawai. Hal ini dapat dilihat dari jumlah pegawai yang memeiliki pengalaman kerja yang memadai pada Balai Besar Industri Hasil Perkebunan Makassar sebanyak 38 orang atau $50,7 \%$ yang berarti telah berpengalaman dalam mengahdapi dinamikia kerja sesuai dengan bentuk-bentuk pengembangan dan orientasi organisasi kerja.jadi dapat dikatakan bhwa pengalaman kerja. Merupakan satu kesatuan yang integral antar ketekunan, pengenalan, dan pemecahan masalah dalam menjalankan aktivitas kerjanya dalam suatu periode kerja.

Kaitannya dengan manajemen sumber daya manusia, pengalman kerj merupakan suatu yang tidak dapat diabaikan dalam meningkatkan kompetensi seseorang untuk dapat meraih kualitas sumber daya manusia. Namun demikian pada penelitian ini, sesuai dengan tanggapan responden secara persial pengalaman kerja menempati posisi terakhir yang mempengaruhi prestasi kerja pegawai. Tetapi secara simultan dengan var- 
iabel bebas lainnya mempengaruhi kinerjapegawai pada Balai Bear Industri Hasil Perkebunan Makassar.

\section{Pengaruh Motivasi terhadap Kinerja Pegawai.}

Hasil penelitian ini menunjukkan bahwa pengaruh motivasi sebagai salah satu unsur kompetensi terhadap kinerja pegawai pada Balai Besar Industri Hasil Perkebunan Makassar juga memegang peranan penting. Nilai standized coefficients Beta dari variabel motivasi adalah 0,295 .

Pada dasarnya hasil penelitian ini menunjukkan bahwa setiap indicator dari setiap variabel $(\mathrm{X})$ yaitu pengetahuan, keterampilan, pengalamn kerja dan motivasi memiliki hubungan yang erat dengan setiap indicator dari variabel terikat (Y) yaitu kinerja. Indikator-indiktor pada variabel pengetahuan, seperti jenjang pendidikan, tingkat pendidikan dan disiplin ilmu sangat menunjang indicator-indikator pada variabel kinerja seperti dapat meningkatkan kualitas kerja, menghasilkan kuantitas kerja yang optimal, bias memberikan inisiatif kerja, dan mampu bekerja dengan tepat.

Indikator-indikator pada variabel keterampilan, seperti kehandalan, kecakapan, dan keahlian menunjang indicator-indikator pada variabel kinerja seperti kualitas, kuantitas, inisiatif dan ketepatan kerja dapat dihasilkan dengan baik, optimal dan sesuai keinginan organisasi atau institusi. Indikator-indikator pada variabel pengalaman kerja, seperti tingkat kematangan kerja, pemahaman kerja, kesetiaan kerja dan tanggung jawab juga menunjang indikator-indikator pada variabel kinerja seperti kualitas, kuntitas, inisiatif dan ketepatan kerja dapat dihasilkan dengan baik, optimal dan sesuai keinginan organisasi atau institusi.

Indikator-indikator pada variabel motivasi, yaitu daya tarik/ syarat imbalan, penguasaan atas pekerjaan, penghagaan, dan pengembangan potensi dapat menunjang indicator-indikator kinerja seperti dapat meningkatkan kualitas kerja, menghasilkan kuantitas kerja yang optimal, bisa memberi inisiatif kerja, dan mampu bekerja dengan tepat. Maka dari itu, dapat dilihat bahwa hubungan setiap indicator variabel pengetahuan, keterampilan, pengalaman kerja dan motivasi dengan indicator kinerja saling berkaitan erat dan menunjang satu sama lainnya.

\section{PENUTUP}

\section{Simpulan}

Berdasarkan hasil penelitian dan pembahasan yang telah dikemukakan sebelumnya, dapat ditarik beberapa kesimpulan yaitu :

1. Secara simultan faktor kompetensi antara lain: pengetahuan, keterampilan, pengalaman kerja dan motivsi perpengaruh positif dan signifikan terhadap kinerja pegawai.

2. Tingkat peengetahuan terbutki berpengaruh dominan dan signifikan terhadap kinerja pegawai pada Balai Besar Industri Hasil Perkebunan Makassar.

\section{Saran}

Dari kesimpulan di atas maka ada beberapa hal yang perlu disarankan dan direkomendasikan kepada Kepala Balai Besar Industri Hasil Perkebunan Makassar yaitu:

1. Agar pegawai yang berpendidikan rendah untuk melanjutkan pendidikannya ke jenjang yng lebih tinggi melalui pemberian Izin ataupun tugas belajar (Bea siswa rintisan gelar). 
2. Agar senantiasa meningkatkan kemampuan pegawai dengan cara memberikan kesempatan untuk mengikuti pelatihan baik formal maupun informal agar tingkat pemahaman pegawai akan lebih berdaya guna dan berhasil guna.

3. Untuk meningkatkan motivasi kerja pegawai yang telah bekerja sebaik mungkin dengan memberikan penghargaan yang layak dan imbalan yang sesuai.

\section{DAFTAR PUSTAKA}

Adnan, Anwar. 1999. Kajian-kajian Keterampilan dan Kompetensi SDM. Jakarta: Erlangga

Amiruddin. 2001. Pendidikan dan Pelatihan. Jakarta: PT. Bina Pustaka

Amrin. 2004. Manajemen Sumber Daya Manusia dan Kinerja. Jakarta: Bina Ilmu.

Dessler, Gary. 2003. Manajemen Sumber Daya Manusia. Jakarta: Prenhallindo

Gibson, Ivancevich. 1994. Organisasi dan Manajemen, perilaku, Struktur, Proses. Jakarta: Erlangga

Gomes, Faustino C, 1995. Manajemen Sumber Daya Manusia. Yokyakarta: Andi Offset Hamid. 2000. Pengelolaan Suber Daya Manusia. Jakarta: Gunung Agung

Handoko, T. Hani. 2001. Manajemen Personlia dan Sumber Daya Manusia, Edisi Kedua Cetakan Kelimabelas. Yokjakarta: BPFE Universitas Gajah Mada,

Makmun, 1999. Tanggung Jawab Dalam Pengelolaan SDM. Bandung: Mandar Maju

Mathis, Robert L. dan Jackson. 2002. Manajemen Sumber Daya Manusia. Edisi Pertama. Jakarta: Salemba empat

Moekijat, 2000, Pengembangan Organisasi. Jakarta: PT.Renika Cipta.

Nirwan, Suganda, 2004, Manajemen Sumber Daya Manusia. Jakarta: Bumi Aksara

Panggabean, 2002, Manajemen Sumber Daya manusia. Cetakan Pertama. Jakarta: Ghalia Indonesia.

Rivai, Veithzal. 2009. Manajemen Sumber Daya Manusia untuk Perusahaan. PT. Raja Grafindo Persada, Jakarta.

Sondang, Siagian P. 2002, Kepemimpinan Organisasi dalam Manajemen SDM. Jakarta: Gunung Agung.

Simamora, Hanry. 2004, Manajemen Sumber Daya Manusia. Edisi Ketiga, Cetakan Pertama. Yogyakarta: STIE-YKPN

Sinabutar, Tora. 2001. Keterampilan dan Profesional SDM. Jakarta: Penerbit Erlangga

Soecipto, Sasono. 1999. Menjadi SDM yang Berpengalaman dan professional. Jakarta: Penerbit Reneka Cipta

Spencer, M, Lyle and Spencer, M, Signe. 1993. Competence at Work Models For Superior Performance. New York: John Wiley \& Son. Inc

Sulastyo, Pramono, 2000. Manajemen Keterampilan Dalam Implementasi Kerja. Bandung: Remaja Rosdakarya.

Tenrigau, A. M. dkk. 2018. Manajemen Sebuah Pengantar. Palopo: Andi Djemma Press

Zwell, Michael, 2000. Creating A Culture of Competence. New York: John Wiley \& Son, Inc 